\title{
Comparison of the Knowledge of Technology, Pedagogy and Content of Educators at Secondary Level
}

* Humaira Akram, PhD Scholar (Corresponding Author)

** Prof. Dr. Samina Malik, Additional Director Distance Education

*** Prof. Dr. Nabi Bux Jumani, Vice President (Administration, Finance \& Planning)

\begin{abstract}
The innovative trends in $21^{\text {st }}$-century instruction have altered the entire landscape of pedagogy. Hence, this worldview move requires technological information and expertise from educators along with knowledge of instructional content. The main topic of the research work is based on a new, interdisciplinary framework for educators' knowledge of technological integration, the professed knowledge of modern equipment, art of teaching, and material. This structure is centered on Shulman's concept of knowledge of instructional material i.e. PCK to comprise information about modern equipment. Therefore, the purpose of this study is to; assess and compare the technical instructional and material understanding (TPACK) of IT educators in government and nongovernment schools. This study has followed a quantitative research approach. The target population comprised of all IT educators working in government and non-government high schools in the urban area of Islamabad. Using a proportionate stratified random sampling technique, 32 IT educators (from government schools) and 40 IT educators (from non-government schools) were selected for sampling. Data were collected using a self-developed research tool. Data analysis was steered using descriptive \& inferential statistics. Outcomes of the study specified a noteworthy variance of government with non-government CS educators -about Technological Knowledge (TK), Content Knowledge (CK), Pedagogical Knowledge (PK), Pedagogical Content Knowledge (PCK), Technical Pedagogic Know-how (TPK) nevertheless, non-noteworthy variance regarding Technological Content Knowledge (TCK) and TPACK.
\end{abstract}

Keywords: TPACK, Computer Science, Secondary Level, Islamabad Introduction

Knowledge of using modern equipment, instruction, and material is described as a multifaceted interaction of content, pedagogy, and know-how, as well as explaining the effective integration of know-how into instruction (Schmid, Brianza, \& Petko, 2021). The TPACK framework is grounded on Shulman's (1987) notion of Pedagogy and Knowledge of content to describe the collaboration of educators' information of educational technologies and Pedagogy and Content Knowledge for successful instruction. Numerous connections arise among these knowledge spheres within an educational context, demonstrating the different forms of knowledge that enlighten a teacher's understanding of the instruction process and the selection and assimilation of instruction resources and approaches.

TPACK is the foundation for effective education with know-how, which requires educators to understand concepts using know-how; educational methods that use technologies in productive tools to deliver content; Knowledge of what makes the concept challenging or stress-free to research work and how know-how can solve it with some difficulties or glitches that learners face. For example, learners' previous concepts, epistemological notions, and understanding about how know-hows are castoff to construct on present knowledge to improve new epistemologies or make stronger deeprooted ones (Tender, Scherer, Siddiq, \& Baran, 2020). To understand, it is claimed that skill of good instruction with know-how includes three essential constituents: material, instruction, and know-how additionally, the associations in them. These core components' connections account for the extensive

\footnotetext{
* Department of Education, International Islamic University Islamabad, Pakistan

Email: humaira.phdedu95@iiu.edu.pk

** International Islamic University, Islamabad Email: samina.malik@iiu.edu.pk

*** International Islamic University Islamabad Email: nb.jumani@iiu.edu.pk
} 
distinctions grasped in the level and excellence of educational know-how assimilation. These three knowledge foundations form the core of the TPACK framework. Nevertheless, TPACK contains seven paradigms that capture the different kinds of knowledge for the efficacious assimilation of know-how into the instruction of explicit material (content).

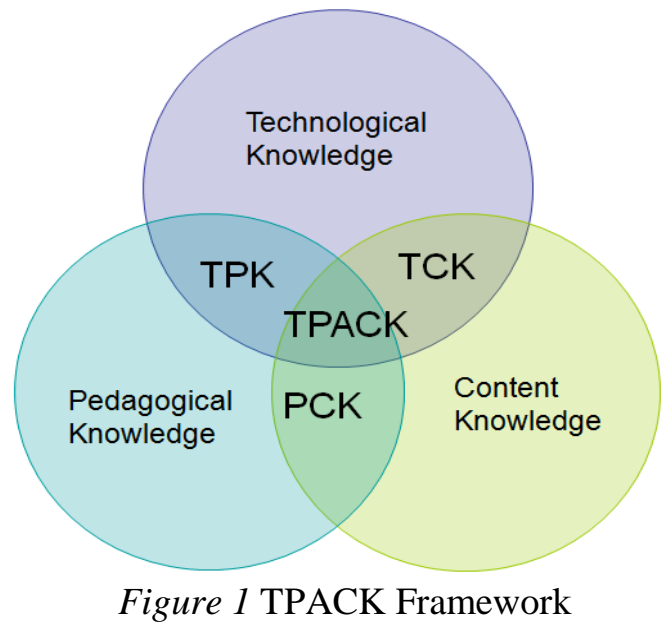

TPACK framework is a knowledge trio of content, pedagogy, and know-how, and this interconnected framework is essential for educators to attain the dynamic instruction \& learning process. As the lack of research in Pakistan in the field of TPACK concerns secondary educators, this research would fill this gap by contributing to the existing literature by exploring the TPACK for IT educators at the secondary level in Islamabad.

\section{Literature Review}

Pakistan is a developing nation, although knowledge of know-how developments and trends are not common in this state; but still, adaptation is very slow. Particularly, at the school level, there is still no suitable structure that would make it easier for educators and students to apply know-how in their instruction-learning process. In addition, TPACK is an entirely new field with limited research studies. For example, Schmid, Brianza, and Petko, (2021) examined the TPACK of university professors from ICT and education departments at the university level reported that both departments previously use know-how in conjunction with their instructional practices, regardless of inadequate know-how infrastructure. Nevertheless, they seemed cooperative in instruction and were open to know-how. Likely, researchers (Tondeur, Scherer, Siddiq, \& Baran, 2020) assessed TPACK and teacher readiness in open and distance education (ODL) for novel academic programs for educators. The research work found that educators have limited information on how to select a know-how that improves teaching and learning methods for a class. Instructors are not so prepared to choose technologies that support the instruction-learning process in their classrooms. Hsu, Liang, and Tsai, (2020) conducted an analytical research work to determine the opinion of teacher educators in Sindhi teacher education institutions about the construction of TPACK and TK. The findings displayed that most teacher educators rated themselves low in the field of TC. Only educators with qualifications in know-how-related fields had a high TK.

Hsu, Liang, and Tsai, (2020) interviewed 1032 high school computer science educators. The findings displayed that the evaluation of $\mathrm{CK}$ and TK was high, which meant that educators were not as much of poised about PCK and TCK. Hsu et al., (2020) abridged the outcomes of several researches and noted that the level of acquired information varies from followers to cohort. For example, educators preparing physics had a moderate level of information, while the outcomes of another research work displayed that instruction educators had a high level of information. Besides, another research work accepted that the level of information of educators was substandard and women educators were also described to take over worthy PK but have difficulties in obtaining TK in comparison to masculine educators (quoted by Mai \& Hamzah, 2016).

Yeh, Hsu, Wu, Hwang, and Lin, (2014) validated the research tool and examined how preparatory educators recognize their TPACK in Estonia. The findings of the research work specified that preparatory educators did not have a PK, but believed that they could integrate know-how well into their instruction approaches. Differences of opinion were also found by gender, age, and curriculum. 
In Hüseyin's (2015) research work, the findings specified that preparatory educators in Turkey observed the uppermost PK and TK values, while the lowermost mean totals were attributed to TCK and PCK factors, nevertheless, Tondeur, Scherer, Siddiq, and Baran, (2020) found that Chinese preparatory educators considered themselves the most influential in terms of TPK and the weakest in terms of CK. Chai et al. (2013) reported that CK was the uppermost-rated factor, in contrast to (Tondeur, Scherer, Siddiq, \& Baran, 2020). In-service educators ranked the uppermost factor in the PK (Simsek, \& Sarsar, 2019) categories. The slightest rated factor in on-job educators was TPACK (Scherer, Tondeur, Siddiq, \& Baran, 2018).

Redmond and Lock (2018) examined the TPACK perception of secondary prospective educators. The findings specified that PSTs had a constructive approach on the way to TPACK and hailed the chance to additionally develop their information and expertise in know-how amalgamation. They understood how the targeted assimilation of know-how improves students learning practices. PSTs were exposed to accepting the execution of TPACK in run-through. At the same time, PSTs assessed the necessity for continuous occupational progress to backing the capability to contrive TPACK effectively in practice.

Scherer, Tondeur, and Siddiq (2017) examined and compared the self-assurance of 388 prospective and 211 performing educators with their instruction experience, expertise, use of knowhow, and gender. The findings displayed that both groups of respondents showed the highest level of self-assurance in the TCK range. While prospective educators had the lowest score in the TPACK, performing educators had the lowest in the TK range. While the TPACK of preparatory math educators was meaningfully lower than that of preparatory science educators, the level of in-service ICT educators was meaningfully higher than that of science, math, and classroom educators, taking into account the TPACK, PCK, and TK areas.

Finally, many researchers have reaffirmed the view that knowledge of know-how integration in education offers an opportunity for active learning, enables students to perform at a higher cognitive level, provides constructivist learning, and promotes scientific research and conceptual change. As few research studies have been conducted in the field of computer education, especially for school-level educators, this research work will fill this gap by contributing to the existing literature primarily in the Pakistani context.

\section{Objectives of Study}

The objectives of the study included:

1. To evaluate the knowledge of technology pedagogy and content knowledge structures of computer science educators.

2. To compare the knowledge of technology pedagogy and content knowledge of IT educators in government and non-government secondary schools.

\section{Hypothesis of the Study}

$\mathrm{Ho}_{1}$ : There is no noteworthy variance in TPACK paradigms between government and nongovernment high school IT educators

\section{Delimitation of the Study}

This research work was limited at the high school level by IT educators from government and nongovernment schools in the city of Islamabad.

\section{Research Methodology}

This research work was descriptive and has followed the quantitative research design.

\section{Population and Sample}

One hundred forty-four high school computer science educators were considered population size; 64 from the government sector and 80 from the non-government sector.

\section{Sample and Sampling Procedure}

Since the population of the study was comprised of two strata, therefore, stratified random sampling procedure was applied to select a sample from each stratum to perform a comparison of government and non-government high school educators. Besides, based on $1 / 2$ sampling fraction, 32 educators from the government school stratum and 40 educators from the non-government school stratum were selected through proportionate stratified sampling.

\section{Instrumentation}

The related literature on TPACK has been studied in-depth and the knowledge base for the development of the research tool in question has been established based on the literature. 


\section{TPACK-CS research tool}

The research tool was designed to examine educators 'TPACKs and related paradigms in IT education. Particularly, the research tool was based on IT content taught in $10^{\text {th }}$ grade. The research tool was comprised of 47 statements. The number of statements in each concept, and the declaration codes, are shown in the subsequent table;

Table 1 declaration outline of Research tool

\begin{tabular}{lcl}
\hline Subscale & No of Statements & Item Code \\
\hline Technological Knowledge (TK) & 6 & TK1-TK6 \\
Content Knowledge (CSCK) & 15 & CSCK7-CSCK21 \\
Pedagogical Knowledge (PK) & 6 & PK22-PK27 \\
Pedagogical Content Knowledge (PCK) & 5 & PCK28-PCK32 \\
Technological Pedagogical Knowledge (TPK) & 4 & TPK33-TPK36 \\
Technological Content Knowledge (TCK) & 4 & TCK37-TCK40 \\
Technological Pedagogical and Content Knowledge & 7 & TPACK41-TPACK47 \\
(TPACK) & & \\
\hline Total & 47 & \\
\hline
\end{tabular}

The TPACK-CS research tool was framed on a 5-point Likert scale format, specifying that 1 strongly disagrees and 5 strongly agrees. This format was chosen subsequent to the literature on "Survey of Preparatory Educators' Knowledge in Instruction and Technology "conducted by Schmid, Brianza, and Petko, (2021). All elements of the research tools in the TPACK paradigms were closedended.

\section{Gathering of Data}

The gathering of data was performed by an individual visit of the investigator with permission of the director of the institutes concerned (employing the research tool stated above). Particularly, the TPACK-CS research tool was directed by high school IT educators. Data collection was directed by the researcher's personal visits to selected respondents.

\section{Data Analysis \& Interpretation}

Descriptive statistics were used to describe TPACK paradigms. This is a suitable analytical method when applied for normal data. With Likert scale data, the mean, as a measure of the crucial trend, cannot be restrained because it is meaningless, i.e., what is the mean of strongly agreeing and disagreeing? The most suitable measure is the mode of most common replies or the median. Particularly, because the data were categorical/regular, i.e., frequencies, median and interquartile range (IQR) were calculated, while the Chi-Square test was used to compare government and nongovernment sector educators. The subsequent is a summary of the data analysis, along with the suitable interpretations.

Table 2 TPACK Paradigms of Government Educators

\begin{tabular}{rllllcc}
\hline S.No & Paradigms & D & N & A & Median & IQR \\
\hline 1. & TK & 0 & 0 & 32 & 4.00 & 0 \\
2. & CK & 0 & 0 & 32 & 4.00 & 1 \\
3. & PK & 2 & 5 & 25 & 4.00 & 0 \\
4. & PCK & $25 K$ & 31 & 4.00 & 0 \\
5. & TPK & 1 & 0 & 31 & 1 \\
6. & TCK & 2 & 1 & 29 & 4.00 & 2 \\
7. & TPACK & 4 & 8 & 20 & 4.00 & 0 \\
\hline
\end{tabular}

Analysis of educators' replies established the consensus of respondents in all statements regarding the relevant median value (4.00) and IQR value $(0,1$, and 2$)$ for the TK, CK, PK, PCK, TPK, TCK subscales.

Table 3

TPACK Paradigms of Non-government Educators

\begin{tabular}{rlccccc}
\hline S.No & Paradigms & D & N & A & Median & IQR \\
\hline 1. & TK & 7 & 3 & 30 & 4.00 & 2 \\
2. & CK & 6 & 10 & 24 & 4.00 & 1 \\
3. & PK & 15 & 3 & 22 & 4.00 & 1 \\
4. & PCK & 16 & 5 & 19 & 3.00 & 2 \\
5. & TPK & 16 & 3 & 21 & 4.00 & 2 \\
6. & TCK & 9 & 8 & 23 & 4.00 & 1 \\
7. & TPACK & 6 & 2 & 32 & 4.00 & 0 \\
\hline
\end{tabular}


The analysis further strengthened the consensus of respondents in most of the statements about TK, CK, PK. PCK, and TPK. The TCK and TPACK subscales as the corresponding median values (4.00) and IQR values $(0,1$, and 2$)$ also support their replies.

Comparison of TPACK Paradigms of Government \& Non-government CS Educators

Table 4 Comparison of TK Construct between Government \& Non-government educators

\begin{tabular}{lllll}
\hline TK1-6 & & 1 & 2 & Total \\
\hline Non-government & Count & 22 & 18 & 40 \\
& Expected Count & 12.8 & 27.2 & 40.0 \\
& \% within Q1_6 & 95.7 & 36.7 & 55.6 \\
Government & Count & 1 & 31 & 32 \\
& Expected Count & 10.2 & 21.8 & 32.0 \\
& \% within Q1_6 & 4.3 & 63.3 & 44.4 \\
\hline$\chi 2=22.00$ & & $\mathrm{df}=1$ & $\mathrm{p}=0.000$ & \\
\hline
\end{tabular}

From table 4, the outcomes exhibited that a p-value of 0.000 is less than 0.05 (level of significance) therefore; no-difference proposition is not accepted affirming that there is a noteworthy link of government with non-government CS educators about TK.

Table 5 Comparison of CK Concept of Government with Non-government educators

\begin{tabular}{lllll}
\hline CK7-21 & & 1 & 2 & Total \\
\hline Non-government & Count & 13 & 27 & 40 \\
& Expected Count & 7.8 & 32.2 & 40.0 \\
& \% within Q7_21 & 92.9 & 46.6 & 55.6 \\
Government & Count & 1 & 31 & 32 \\
& Expected Count & 6.2 & 25.8 & 32.0 \\
& \% within Q7_21 & 7.1 & 53.4 & 44.4 \\
\hline \multirow{2}{*}{$2=9.79$} & & $\mathrm{df}=1$ & $\mathrm{p}=0.002$ & \\
\hline
\end{tabular}

From Table 5, the outcomes revealed that the $0.002 \mathrm{p}$-value is less than 0.05 (significance level), therefore; the no-difference proposition is rejected, stating that there is a noteworthy relationship between government and non-government CS educators concerning CK.

Table 6 Comparison of PK Concept of Government with Non-government educators

\begin{tabular}{lllll}
\hline PK22-27 & & 1 & 2 & Total \\
\hline Non-government & Count & 23 & 17 & 40 \\
& Expected Count & 15.6 & 24.4 & 40.0 \\
& \% within Q22_27 & 82.1 & 38.6 & 55.6 \\
Government & Count & 5 & 27 & 32 \\
& Expected Count & 12.4 & 19.6 & 32.0 \\
& \% within Q22_27 & 17.9 & 61.4 & 44.4 \\
\hline$\chi 2=13.1$ & & $\mathrm{df}=1$ & $\mathrm{p}=0.000$ & \\
\hline
\end{tabular}

From Table 6, the findings showed that the $0.000 \mathrm{p}$-value is less than 0.05 (significance level), therefore; the no-difference proposition is rejected, stating that there is a noteworthy relationship between government and non-government CS educators concerning PK.

Table 7 Comparison of PCK Concept of Government with Non-government educators

\begin{tabular}{lllll}
\hline PCK28-32 & & 1 & 2 & Total \\
\hline Non-government & Count & 18 & 22 & 40 \\
& Expected Count & 12.8 & 27.2 & 40.0 \\
& \% within Q28_32 & 78.3 & 44.9 & 55.6 \\
Government & Count & 5 & 27 & 32 \\
& Expected Count & 10.2 & 21.8 & 32.0 \\
& \% within Q28_32 & 21.7 & 55.1 & 44.4 \\
\hline$\chi 2=7.05$ & & $\mathrm{df}=1$ & $\mathrm{p}=0.008$ & \\
\hline
\end{tabular}

From Table 7, the findings displayed that the 0.008 p-value was less than 0.05 (significance level), therefore; the no-difference proposition is rejected, stating that there is a noteworthy relationship between government and non-government CS educators concerning PCK. 


\begin{tabular}{lllll}
\hline \multicolumn{5}{l}{ Table 8 Comparison of TPK Construct between Government \& Non-government educators } \\
\hline TPK33-36 & & 1 & 2 & Total \\
\hline Non- & Count & 24 & 16 & 40 \\
government & Expected Count & 16.7 & 23.3 & 40.0 \\
& \% within Q33_36 & 80.0 & 38.1 & 55.6 \\
Government & Count & 6 & 26 & 32 \\
& Expected Count & 13.3 & 18.7 & 32.0 \\
& \% within Q33_36 & 20.0 & 61.9 & 44.4 \\
\hline$\chi 2=12.44$ & & $\mathrm{df}=1$ & $\mathrm{p}=0.000$ & \\
\hline
\end{tabular}

From Table 8, the findings displayed that the $0.000 \mathrm{p}$-value was less than 0.05 (significance level), therefore; the no-difference proposition is rejected, stating that there is a noteworthy relationship between government and non-government CS educators concerning TPK.

Table 9 Comparison of TCK Concept of Government with Non-government educators

\begin{tabular}{lllll}
\hline TCK37-40 & & 1 & 2 & Total \\
\hline Non-government & Count & 20 & 20 & 40 \\
& Expected Count & 28.3 & 21.7 & 40.0 \\
& \% within Q37_40 & 60.6 & 51.3 & 55.6 \\
Government & Count & 13 & 19 & 32 \\
& Expected Count & 14.7 & 17.3 & 32.0 \\
& \% within Q37_40 & 39.4 & 48.7 & 44.4 \\
\hline$\chi 2=0.629$ & & $\mathrm{df}=1$ & $\mathrm{p}=0.428$ & \\
\hline
\end{tabular}

From Table 9, the findings showed that the p-value of 0.428 is greater than 0.05 (significance level); we accept the no-difference proposition that there is no noteworthy relationship between government and non-government CS educators concerning TCK.

Table 10 Comparison of TPACK Construct between Government \& Non-government educators

\begin{tabular}{lllll}
\hline TPACK 41-47 & & 1 & 2 & Total \\
\hline Non-government & Count & 5 & 35 & 40 \\
& Expected Count & 4.4 & 35.6 & 40.0 \\
& \% within Q41_47 & 62.5 & 54.7 & 55.6 \\
Government & Count & 3 & 29 & 32 \\
& Expected Count & 3.6 & 28.4 & 32.0 \\
& \% within Q41_47 & 37.5 & 45.3 & 44.4 \\
\hline$\chi 2=0.176$ & & $\mathrm{df}=1$ & $\mathrm{p}=0.675$ & \\
\hline
\end{tabular}

From Table 10, the findings showed that a p-value of 0.675 is greater than 0.05 (significance level); we accept the no-difference proposition that there is no noteworthy relationship between government and non-government CS educators concerning TPACK.

\section{Discussion \& Conclusion}

The findings of this research work showed that government CS educators displayed accord on very nearly total sub-ranges of TPACK apart from CK6 (first-generation languages use decimal code), while non-government CS educators also agreed with TK5. On total sub-ranges (sufficient opportunities to use different ICT media.) and PCK1 (understanding of choosing operative instruction attitudes to direct students' IT discerning), PCK4 (collaborative erudition available via the Internet), and PCK5 (storage devices can be taught with a software approach). More particularly, in-service educators agreed with the TPACK subscales. In their research work with in-service teacher educators, Bal and Kara (2013) also indicated that educators found themselves contented at the "Consensus" level about TPACK. Alike findings have been found in the literature (Chai et al., 2013). Chai et al. (2010) reported that TK, PK, and CK are all noteworthy predictors of educators 'TPACK, and PK has the greatest impact. In the same mindset, Özgür, (2020) reported that CK is the highest-rated factor.

Furthermore, Hsu, Tsai, Chang, and Liang, (2017) examined how educators perceive their TPACK, and the findings specified that educators were missing from PK, but found that they could integrate know-how well into their instruction. The findings of the existing research work are alike to those described in the earlier collected works (Hsu, Liang, \& Tsai, 2020), i.e., in-service educators rated PK and CK as the highest aspect. Even though the lowermost valued aspect in educators was TPACK (Tondeur, Scherer, Siddiq, \& Baran, 2020), this finding disfavoured the findings of the current research work. Nevertheless, Blau, Peled, and Nusan (2016) found that high school IT educators were less assured about PCK. This result is analogous to the outcome of this research work. 
Comparison of TPACK paradigms between (government and non-government) CS educators specified a noteworthy variance between government and non-government CS educators for TK, CK, PK, PCK, TPK, but not a noteworthy variance for TCK and TPACK. This result is matching with the result described by Hsu, Liang, and Tsai, (2020) who examined educators' TPACK and specified that there were no noteworthy variances in educators in the CK between the two programs. Besides, the TPACK subscales were meaningfully related to each other, i.e., CK and PK meaningfully anticipated the value of TPACK. Government CS educators exhibited unanimity on total sub-ranges of TPACK apart from CK6, while non-government CS educators also disclosed unanimity on total sub-extent apart from TK5 and PCK1, PCK4, and PCK5. Comparison of TPACK concepts of government with non-government CS educators found a noteworthy variance between government and nongovernment CS educators for TK, CK, PK, PCK, TPK, nevertheless, there was no noteworthy variance for TCK and TPACK.

\section{Recommendation}

Based on the findings and conclusions, the subsequent recommendation was made:

The findings specified polarized replies on some dimensions of TK, CK, and PCK in most nongovernment educators and CK government educators, so these dimensions can be updated by shaping conferences/training workshops. In this mindset, the content of seminars/trainings should include; various ICT media (TK5), paragraph formatting (CK13), computer programming language (CK6), effective instruction approaches to control students 'IT thinking (PCK1), collaborative learning via the Internet (PCK4) and software approach to instruction storage devices (PCK5).

\section{References}

Bal, M. S., \& Karademir, N. (2013). Sosyal Bilgiler öğretmenlerinin teknolojik pedagojik Alan bilgisi (TPAB) konusunda öz-değerlendirme seviyelerinin belirlenmesi. Pamukkale Üniversitesi Eğitim Fakültesi Dergisi, 34(2), 15-32

Blau, I., Peled, Y., \& Nusan, A. (2016). Technological, pedagogical and content knowledge in one-toone classroom: educators developing "digital wisdom". Interactive Learning Environments, 24(6), 1215-1230.

Chai, C. S., Koh, J. H. L., \& Tsai, C.-C. (2010). Facilitating Pre-service Educators' Development of Technological, Pedagogical, and Content Knowledge (TPACK). Educational Technology \& Society, 13(4), 63-73.

Chai, C., Chin, C., Koh, J., \& Tan, C. (2013). Exploring Singaporean Chinese Language Educators' Technological Pedagogical Content Knowledge and its Relationship to the Educators' Pedagogical Beliefs. The Asia-Pacific Education Researcher, 22(4), 657-666. doi: 10.1007/s40299-013-0071-3

Hsu, C. Y., Liang, J. C., \& Tsai, M. J. (2020). Probing the structural relationships between educators' beliefs about game-based instruction and their perceptions of technological pedagogical and content knowledge of games. Technology, Pedagogy and Education, 29(3), 297-309.

Hsu, C. Y., Tsai, M. J., Chang, Y. H., \& Liang, J. C. (2017). Surveying in-service educators' beliefs about game-based learning and perceptions of technological pedagogical and content knowledge of games. Journal of Educational Technology \& Society, 20(1), 134-143.

Lin, C.Y., Kuo, Y.C. \& Ko, Y.Y. (2015). A Study of Pre-Service Educators' Perception of Technological Pedagogical Content Knowledge on Algebra. Journal of Computers in Mathematics and Science Instruction, 34(3), 327-344.

Mai, M., \& Hamzah, M. (2016). Primary Science Educators' Perceptions of Technological Pedagogical and Content Knowledge (TPACK) In Malaysia. European Journal of Social Sciences Education and Research, 6(2), 167. Doi: 10.26417/ejser.v6i2.p167-179

Özgür, H. (2020). Relationships between educators' technostress, technological pedagogical content knowledge (TPACK), school support and demographic variables: A structural equation modeling. Computers in Human Behavior, 112, 106468.

Redmond, P., \& Lock, J. (2018). Secondary pre-service educators' perceptions of Technical Pedagogical Content Knowledge (TPACK): What do they really think? Australasian Journal of Educational Technology. Doi: 10.14742/ajet.4214

Scherer, R., Tondeur, J., \& Siddiq, F. (2017). On the quest for validity: Testing the factor structure and measurement invariance of the technology-dimensions in the Technological, Pedagogical, and Content Knowledge (TPACK) model. Computers \& Education, 112, 1-17. 
Scherer, R., Tondeur, J., Siddiq, F., \& Baran, E. (2018). The importance of attitudes toward technology for pre-service educators' technological, pedagogical, and content knowledge: Comparing structural equation modeling approaches. Computers in Human Behavior, 80, $67-$ 80.

Schmid, M., Brianza, E., \& Petko, D. (2021). Self-reported technological pedagogical content knowledge (TPACK) of pre-service educators in relation to digital technology use in lesson plans. Computers in Human Behavior, 115, 106586.

Shulman, L. S. (1986). Those who understand: Knowledge growth in instruction. Educational Researcher, 15(2), 4-14.

Shulman, L. S. (1987). Knowledge and instruction: Foundations of the new reform. Harvard Educational Review, 57(1), 1-22.

Simsek, Ö. \& Sarsar, F. (2019). Investigation of the Self-Efficacy of the Educators in Technological Pedagogical Content Knowledge and Their Use of Information and Communication Technologies. World Journal of Education, 9(1), 196-208.

Tender, J., Scherer, R., Siddiq, F., \& Baran, E. (2020). Enhancing pre-service educators' technological pedagogical content knowledge (TPACK): a mixed-method study. Educational Technology Research and Development, 68(1), 319-343.

Yeh, Y. F., Hsu, Y. S., Wu, H. K., Hwang, F. K., \& Lin, T. C. (2014). Developing and validating technological pedagogical content knowledge-practical (TPACK-practical) through the Delphi survey technique. British Journal of Educational Technology, 45(4), 707-722. 